\title{
Comparative effects of cantharidin and endothall on gene expression and activity of antioxidant enzymes in Cichorium intybus L.
}

\author{
Yalda GHOTBZADEH KERMANI ${ }^{1}$, Ramazan Ali KHAVARI NEJAD ${ }^{1}$, Homa MAHMOODZADEH ${ }^{2,3}$, \\ Khadijeh SHAHROKH ABADI ${ }^{2}$
}

Received July 24, 2019; accepted September 04, 2020.

Delo je prispelo 24. julija 2019, sprejeto 04. septembra 2020.

Comparative effects of cantharidin and endothall on gene expression and activity of antioxidant enzymes in Cichorium intybus $\mathrm{L}$.

Abstract: Cantharidin and its analog, endothall, are known to have phytotoxic effects and their mechanism of action involves the inhibition of phosphatases. Enzymes and antioxidant compounds act as barriers against phytotoxic compounds. Catalase and peroxidase are among the most important antioxidant enzymes. Cichorium intybus L. has traditionally been used for its medicinal properties and contains various phytochemical and enzymatic compounds. The present study aimed to investigate the comparative effects of cantharidin and endothall with concentration of $2.5,5.5$ and $10 \mu \mathrm{g} \mathrm{ml}^{-1}$ on the changes in the gene expression of catalase and glutathione peroxidase. Furthermore, we assess the activities of these enzymes in the shoots and roots of Cichorium intybus L.. According to the findings, the expression of catalase and glutathione peroxidase increased in the samples treated with cantharidin more than endothall compared to the controls in both shoot (the most significant is in cantharidin with $2.5 \mu \mathrm{g} \mathrm{ml}^{-1}$ concentration) and root samples (the most significant is in cantharidin with 5.5 $\mu \mathrm{g} \mathrm{ml}^{-1}$ concentration). In addition, the activity of catalase and concentrations of cantharidin $\left(2.5 \mu \mathrm{g} \mathrm{ml}^{-1}\right)$ in shoot samples led to the more intense stimulation of catalase and glutathione peroxidase compared to root samples. We suggest that cantharidin and endothall have negative effect on expression and absorption of antioxidant enzymes.

Key words: cantharidin; catalase; Cichorium intybus L.; endothall; glutathione reroxidase
Primerjalni učinki kantaridina in endotala na izražanje genov in aktivnost antioksidacijskih encimov pri navadnem potrošniku (Cichorium intybus L.)

Izvleček: Kantaridin in njegov analog endotal sta poznana po fitotoksičnih učinkih, pri katerih njun mehanizem delovanja vsebuje inhibicijo fosfataz. Encimi in antioksidacijske spojine tvorijo bariero proti fitotoksičnim spojinam. Katalaza in peroksidaza sta med najpomembnejšimi antioksidacijskimi encimi. Navadni potrošnik (Cichorium intybus L.) se tradicionalno uporablja kot zdravilna rastlina zaradi vsebnosti različnih fitokemikalij in encimov. V raziskavi so bili preučevani primerjalni učinki kantaridina in endotala $\mathrm{v}$ koncentracijah $2,5,5,5$ in $10 \mu \mathrm{g} \mathrm{ml}^{-1}$ na spremembe v izražanju genov za katalazo in glutation peroksidazo. Aktivnosti teh dveh encimov so bile ocenjene $\mathrm{v}$ poganjkih in koreninah navadnega potrošnika. Izsledki so pokazali, da se je izražanje genov za katalazo in glutation peroksidazo bolj povečalo v vzorcih, ki so bili tretirani s kantaridinom kot $\mathrm{v}$ tistih tretiranih $\mathrm{z}$ endotalom $\mathrm{v}$ primerjavi $\mathrm{s}$ kontrolo, tako v poganjkih (najznačilnejši učinek je imela koncentracija kantaridina $2,5 \mu \mathrm{g} \mathrm{ml}^{-1}$ ) kot v koreninah (najznačilnejši učinek je imela koncentracija kantaridina $5,5 \mu \mathrm{g} \mathrm{ml}^{-1}$ ). Dodatno sta aktivnost katalaze in koncentracija kantaridina $(2,5$ $\left.\mu \mathrm{g} \mathrm{ml}^{-1}\right) \mathrm{v}$ vzorcih poganjkov vodili $\mathrm{k}$ intenzivnejši stimulaciji katalaze in glutation peroksidaze v primerjavi z vzorci korenin. Predpostavljamo, da imata kantaridin in endotal negativni učinek na izražanje genov antioksidacijskih encimov in na njihovo absoprcijo.

Ključne besede: kantaridin; katalaza; Cichorium intybus L.; endotal; glutatione peroksidaza

1 Islamic Azad University, College of Basic Science and Research Branch, Department of Botany, Tehran, Iran

2 Islamic Azad University, Mashhad branch, Department of Biology, Mashhad, Iran

3 Corresponding author, e-mail: homa_mahmoodzadeh@yahoo.com 


\section{INTRODUCTION}

Cichorium intybus L. belongs to the Asteraceae family (Heimler et al., 2009) and Wild chicory or blue daisy C.intybus is a diploid plant species $(2 \mathrm{n}=18)$ (Funk et al., 2005). The shoots of C.intybus could be as high as 0.5-1.5 meters in the wild state, and they may even exceed two meters. It is cultivated as an ornamental and medicinal plant across Europe. In Iran, C. intybus grows in mountainous regions, as well as Khorasan, Guilan, Mazandaran and Tehran provinces.

Chicory is an important medicinal plant which accumulates various specific organic compounds, such as storage polysaccharide inulin, sesquiterpene lactones, cumarins, phenolic acids and flavonoids (Bais \& Ravishankar, 2001; Senderski, 2009). Flavonoids and terpenoids are among the important compounds found in $C$. intybus. Some cultivars of this plant are widely cultivated in countries such as the United States, India, and New Zealand as a fodder plant to feed livestock. Furthermore, C. intybus has been traditionally used as a medicinal herb. As such, the phytochemical and enzymatic compounds found in C. intybus are of almost importance (Abbas et al., 2015). Cantharidin is a toxic terpenoid compound, which is found in the beetles of Meloidae and Oedemeridae families. This natural terpenoid is also produced by the blister beetle (Epicauta spp.) and Spanish flies (Lytta vesicatoria (L., 1758)) as a protection mechanism (Bajsa et al., 2011). Cantharidin has been used as a medicine in China since 2000 years ago. This compound is of medical and economic significance due to its medicinal proprieties and severe toxicity in livestock. Nevertheless, its usage has recently become restricted in medicine due to its high toxicity and adverse effects (Young, 2017). Previous studies have denoted that cantharidin affects cells through inhibiting phosphatases proteins (PPTs) 1 and 2 . Phosphatases are involved in various cellular functions through phosphorylation-dephosphorylation and are responsible for conducting phosphorylation-dependent signals. The other mechanisms in this regard include activating apoptosis and blocking all the apoptosis inhibitors (Ward et al., 2017). In addition, PPTs control several plant cell functions, such as pathway crosstalk, light perception, response to pathogens, and hormonal functions (Ward et al., 2017a; Rikin \& Rubin, 1993). Considering the effectiveness of PPTs, they have been applied to obtain various compounds for special purposes. Endothall herbicide is one of the analogs of these compounds (Duke \& Powles, 2008).

Endothall (7-oxabicyclo heptane-2,3-dicarboxylic acid) was introduced in the 1950 with the commercial name ACCELERATE (Duke \& Powles, 2008a). Despite its history, endothall remains one of the several herbi- cides to be used widely. Considering its mechanism of action, endothall inhibits the entrance of leucine amino acid into the protein structure in different parts of plants. At high concentrations, endothall could even inhibit the synthesis of lipids. The plants affected by this toxin die in a browned form and decrease the light genes expression. According to the WSSA Herbicide Handbook, endothall affects the cell membrane, as well as a wide range of molecular pathways, which are not clearly identified (Dayan \& Watson, 2011). In addition, previous findings have indicated that cantharidin and endothall are both specific inhibitors of phosphatases proteins, and the phosphatase protein functioning in plants is inhibited more effectively by endothall compared to cantharidin (Bajsa et al., 2012).

The inhibition of phosphatases proteins in plants could damage the plant structure. As such, plants have developed various strategies to respond to the herbicide toxicity. For instance, the antioxidant system is a considerable defense mechanism in plants, which is activated through focused responses with the involvement of various enzymes, including superoxide dismutase, catalase, peroxidase, ascorbate peroxidase, glutathione reductase, and glutathione transferase. Catalase is an important enzyme, which is responsible for a major part of the antioxidant defense in plants. Moreover, reports have suggested that following catalase, peroxidase plays a key role in the removal of hydrogen peroxide (Bajsa et al., 2012a).

To date, no studies have evaluated the effects of cantharidin and endothall on the gene expression of antioxidant enzymes, as well as the changes in the activities of catalase and glutathione peroxidase proteins. Considering the adverse effects of these herbicides on cell physiology (fodder and medicinal plants), the present study aimed to investigate the effects of cantharidin and endothall on the expression of catalase and glutathione peroxidase antioxidant genes in Cichorium intybus (L.).

\section{MATERIALS AND METHODS}

\subsection{CULTIVATION, TREATMENT, AND SAM- PLING OF CICHORIUM INTYBUS (L.)}

In this study, the seeds of Cichorium intybus L. were obtained from Pakan Bazr Company in Isfahan, Iran. The seeds were placed in suitable pots for germination, and daily irrigation was performed for five days with $200 \mathrm{ml}$ of water per week. After this period and when the plants were in the two-leaf stage, treatment of the samples was initiated using $200 \mathrm{ml}^{\text {week }}{ }^{-1}$ of each concentration, and plants were water-sprayed every other day.

In order to determine the proper concentrations of cantharidin and endothall, the plants were randomly 
treated with 10, 50, 100, and $150 \mu \mathrm{g} \mathrm{ml}^{-1}$, and the results of the initial cultivation indicated that the plants had no germination at the other concentrations than $10 \mu \mathrm{g} \mathrm{ml}^{-1}$. Therefore, the concentration range of less than $10 \mu \mathrm{g} \mathrm{ml}^{-1}$ was selected for the main experiments. After determining the proper concentrations, cultivated seeds were treated by $2.5,5.5$ and $10 \mu \mathrm{g} \mathrm{ml}^{1-}$ for endothall and cantharidin respectively.

Plant treatments were performed using $400 \mathrm{ml}$ of each treatment. Experiments were conducted in controlled laboratory conditions $\left(25 \pm 1 \mathrm{C}^{\circ}, 16: 8 \mathrm{~h}(\mathrm{~L}: \mathrm{D})\right.$, and harvesting was accomplished after two months of vegetative growth. At the next stage, separate samples were obtained from the roots and shoots of plants.

\subsection{RNA EXTRACTION AND CDNA SYNTHESIS}

Changes in the expression of catalase and glutathione peroxidase genes were examined in the shoots and roots $(2 \mathrm{~cm})$ of the samples. RNA extraction was performed using a Fermentas kit in accordance with the instructions of the manufacturer. Nanodrop was used to assess the presence and evaluate the purity of the extracted RNA. To remove the DNA impurities, we applied the DNase enzyme (Fermentas DNase I, RNase-free) in accordance with the protocol.

At the next stage, the cDNA was produced from the extracted RNA using RevertAid First Strand cDNA kit based on the proposed method in its protocol (According to the Fermentas kit ). Eventually, the cDNA was used as the model DNA in polymerase chain reaction (PCR).

\subsection{EXAMINATION OF THE CHANGES IN THE EXPRESSION OF THE CATALASE AND GLU- TATHIONE PEROXIDES GENES USING QRT- PCR}

Real-time PCR was employed to examine the changes in the expression of catalase and glutathione peroxidase genes using a PCR device (Light Cycler, Bio $\mathrm{Rad}$ ) and SYBR Green color with the reaction volume of $20 \mathrm{ml}$, which consisted of $10 \mathrm{ml}$ of the master mix containing SYBR Green, two $\mathrm{ml}$ of the left primers, and two $\mathrm{ml}$ of the right primers (Table 1 ).
The duration of the cycles was set at three minutes at the temperature of $95^{\circ} \mathrm{C}$ before 40 cycles (10 seconds at $95^{\circ} \mathrm{C}$ ), and the final stage lasted for 30 seconds at the temperature of $60^{\circ} \mathrm{C}$ in accordance with the protocol of the SYBR Green kit (Sanders \& Lee, 2013). Eventually, the melting curve was drawn, and the changes in the expression of catalase and glutathione peroxidase genes were compared with the control samples.

\subsection{MEASUREMENT OF ENZYMATIC ACTIVITY}

To measure the activity of enzymes, $0.5 \mathrm{~g}$ of the fresh shoot or root tissue of the plant was milled in liquid nitrogen. Afterwards, $50 \mathrm{mM}$ of phosphate buffer containing $1 \%$ polyvinyl pyrrolidine and EDTA $(1 \mathrm{mM})$ were added to the milled tissues, and the mixture was centrifuged at the temperature of $4{ }^{\circ} \mathrm{C}$ for 20 minutes at $14,000 \mathrm{~g}$. The supernatant fluid was collected to measure the proteins and preserved at the temperature of $-20^{\circ} \mathrm{C}$.

\subsection{MEASURING THE ACTIVITY OF CATALASE}

To measure the activity of catalase, a reaction mixture composed of $20 \mathrm{ml}$ of the extract, $980 \mathrm{ml}$ of phosphate buffer $(50 \mathrm{mM})$, and oxygenated water $(15 \mathrm{mM})$ was prepared, and the reaction was rapidly initiated by adding oxygenated water. Reduced absorption of hydrogen peroxide was recorded as the changes in absorption over time at the wavelength of 240 nanometers. The enzyme activity was expressed in terms of $\mu \mathrm{mol} \mathrm{g}^{-1}$ of fresh tissue per minute (Marschner \& Cakmak, 1992).

\subsection{MEASURING THE ACTIVITY OF GLU- TATHIONE PEROXIDASE}

The activity of glutathione peroxidase was measured based on the reduction of oxidized glutathione by the glutathione reductase enzyme with the consumption of nicotinamide adenine dinucleotide phosphate $(\mathrm{NADPH})$. To perform the experiment, the reaction mixture containing $250 \mathrm{ml}$ of potassium phosphate buffer $(100 \mathrm{mM}), 120 \mathrm{ml}$ of NADPH $(1 \mathrm{mM}), 50 \mathrm{ml}$ of oxidized glutathione $(10 \mathrm{mM})$, and $480 \mathrm{ml}$ of distilled water

Table 1: Sequence of utilized primers(primers are designed according to the genes used, from the NCBi database)

\begin{tabular}{lll}
\hline Gene & Right Sequence Primer & Left Sequence Primer \\
\hline Catalase & CATCTGATTGAAAAAGCTTGCG & TTTGAGGGCTTCCAGGTTG \\
Glutathione Peroxidase & GTCACAAGAACACCGCTTT & CGCAACAATTCGCCTT \\
\hline
\end{tabular}


was prepared. Following that, $100 \mathrm{ml}$ of the root or shoot extract of the plant were added to the reaction mixture and assorted.

At the next stage, the changes in the absorption were read at 340 nanometers for $120 \mathrm{~s}$ based on the kinetic method using a spectrophotometer. The enzyme activity was expressed based on the changes in the absorption $\mathrm{min}^{-1} \mathrm{mg}^{-1}$ protein (Mac Adam, 1992).

\subsection{STATISTICAL ANALYSIS}

The experiments were run in a fully random design format with three replications. Data analysis was performed by SPSS 22.0 software, and the minimum significance level of $p \leq 0.05$ was considered to compare the means.

\section{RESULTS AND DISCUSSION}

\subsection{EVALUATING THE CHANGES IN THE EX- PRESSION OF THE CATALASE AND GLU- TATHIONE PEROXIDASE GENES USING QRT- PCR}

3.1.1 Changes in the expression of the catalase and glutathione peroxidase genes in the shoots of the samples treated with cantharidin and endothall

According to the investigation of the changes in the expression of catalase in the samples treated with endothall, the changes in the expression of this gene were significant at the concentration of $5.5 \mu \mathrm{g} \mathrm{ml}^{-1}$ compared to the controls. Furthermore, the changes in the catalase gene in the samples treated with cantharidin were considered significant at the concentrations of $2.5 \mu \mathrm{g} \mathrm{ml}^{-1}$. In the samples treated with cantharidin, the catalase gene had a more significant elevated expression compared with the samples treated with endothall.

According to the investigation of the changes in the glutathione peroxidase gene in the samples treated with endothall, the expression of this gene increased in the shoots of the samples treated with $2.5 \mu \mathrm{g} \mathrm{ml}^{-1}$ of endothall compared to the control. Moreover, in the shoot samples of the plants treated with cantharidin, the elevation of the changes in the expression of this gene was observed at the concentrations of 2.5 and $10 \mu \mathrm{g} \mathrm{ml}^{-1}$. Comparison of the changes in the expression of the peroxidase gene in the samples treated with cantharidin and endothall indicated that the increase in the expression of this antioxidant gene was more significant with cantharidin.

3.1.2 Changes in the expression of the catalase and glutathione peroxidase genes in the roots of the samples treated with cantharidin and endothall

According to the investigation of the changes in the expression of the catalase gene in the roots of the samples treated with endothall, the changes in the expression of this gene were significant at the concentration of $10 \mu \mathrm{g} \mathrm{ml}^{-1}$ compared to the controls, while no significant changes were denoted at the other concentrations compared to the control. On the other hand, the results of the changes in the glutathione peroxidase and catalase genes in the samples treated with cantharidin indicated that the expression of these genes had a significant difference compared to the controls. Moreover, the expres-

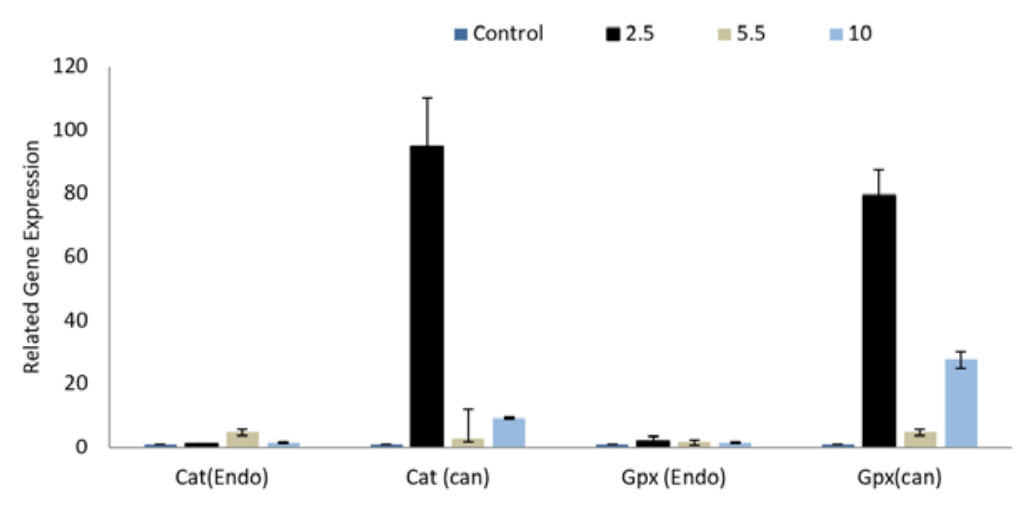

Treatment concentrations $\left(\mu \mathrm{g} \mathrm{ml}{ }^{-1}\right)$

Figure 1: Changes in the expression of catalase and glutathione peroxidase antioxidant genes in the shoot of Chicorium intybus $\mathrm{L}$. treated with endothall and cantharidin $\left(\mu \mathrm{g} \mathrm{ml}^{-1}\right)$ 


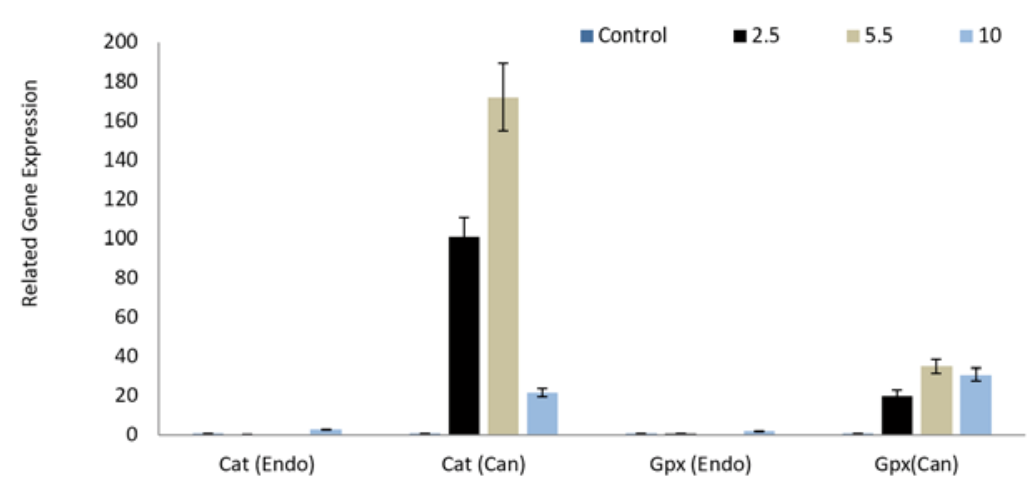

Treatment concentrations $\left(\mu \mathrm{g} \mathrm{ml}{ }^{1}\right)$

Figure 2: Changes in the expression of catalase and glutathione peroxidase antioxidant genes in the root of Chicorium intybus L. treated with endothall and cantharidin $\left(\mu \mathrm{g} \mathrm{ml}^{-1}\right)$

sion of these genes increased in the roots of the samples treated with $5.5 \mu \mathrm{g} \mathrm{ml}^{-1}$ of cantharidin compared to the controls. Comparison of the changes in the expression of the peroxidase and catalase genes in the samples treated with cantharidin and endothall demonstrated that the increased expression of these antioxidant genes was more significant with cantharidin.

\subsection{THE ACTIVITY OF CATALASE AND GLU- TATHIONE PEROXIDASE ENZYMES}

\subsubsection{Measurement of the absorption of catalase and glutathione peroxidase in the shoot of the sam- ples treated with cantharidin and endothall}

Comparison of the mean absorption of catalase in the shoots of the samples treated with endothall indicated that the mean absorption of catalase in the shoots had a significant difference with the controls at the concentrations of $5.5 \mu \mathrm{g} \mathrm{ml}^{-1}$, while the mean absorption showed no significant difference at the concentrations of 2.5 and $5.5 \mu \mathrm{g} \mathrm{ml}^{-1}$.

Comparison of catalase absorption in the shoots of the samples treated with cantharidin showed a significant difference in the mean absorption of this enzyme between the shoots of the control samples and those treated with the concentrations of $2.5 \mu \mathrm{g} \mathrm{ml}^{-1}$, then $10 \mu \mathrm{g} \mathrm{ml}^{-1}$. As can be observed, changes in the cantharidin concentration increased the mean absorption of catalase in the shoots of the plants compared to the controls. According to the comparison of the activity of catalase in the samples treated with cantharidin and endothall, the maximum changes in the activity of this enzyme were observed in the samples treated with cantharidin.
The mean absorption of glutathione peoxidase was considered significant in the shoots of the Cichorium intybus $\mathrm{L}$. samples treated with endothall at all the concentrations compared to the controls. The maximum changes in the samples treated with endothall were observed in the samples treated with $5.5 \mu \mathrm{g} \mathrm{ml}^{-1}$. Furthermore, the activity of glutathione peroxidase increased significantly in the shoots of the samples treated with cantharidin compared to the controls. In addition, the maximum enzyme activity was observed at the concentration of $2.5 \mu \mathrm{g} \mathrm{ml}^{-1}$ in these treatment groups. Comparison of the activity of glutathione peroxidase in the samples treated with cantharidin and endothall indicated that the maximum changes in the activity of this enzyme were observed in the samples treated with cantharidin.

\subsubsection{Measurement of the absorption of catalase and glutathione peroxidase in the roots of the sam- ples treated with cantharidin and endothall}

Comparing the mean absorption of catalase in the root treated with endothall indicated that the mean absorption of catalase in the root indicated a significant difference with the control at the concentration of $10 \mu \mathrm{g} \mathrm{ml}^{-1}$ other concentrations did not show any significant difference. Cantharidin reveals a significant difference at the concentrations of control and the maximum difference was in $5.5 \mu \mathrm{g} \mathrm{ml}^{-1}$ Comparison of the activity of glutathione peroxidase in the samples treated with cantharidin and endothall indicated that the maximum changes in the activity of this enzyme were observed in the samples treated with cantharidin.

In this research, the maximum extent of the increased expression of catalase and glutathione per- 

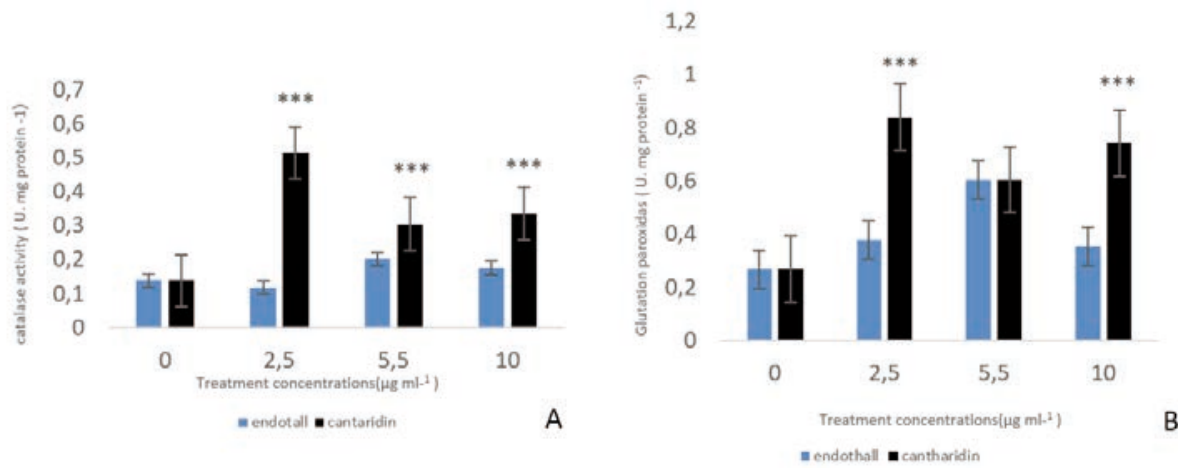

Figure 3: Changes in the activity of catalase enzyme in the shoot samples of Chicorium intybus L. plant treated with different concentrations of endothall and cantharidin (A), changes in the activity of glutathione peroxidase enzyme in the shoot samples of Chicorium intybus L. with different concentrations of endothall and cantharidin (B) ${ }^{* * *}$ Representing significant effects at $0.1 \%$ probability level.
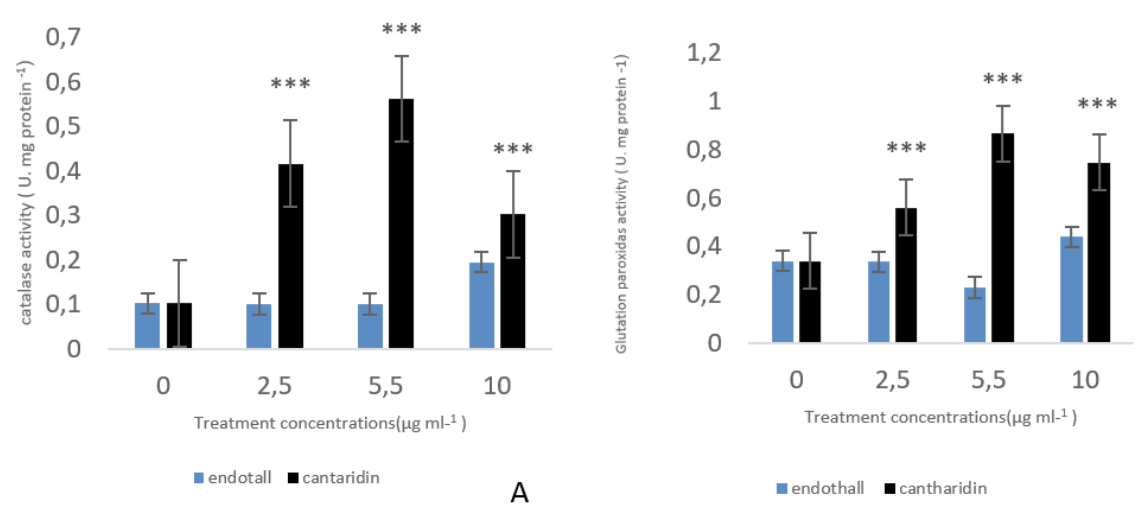

B

Figure 4: Changes in the activity of catalase enzyme in the root samples of Chicorium intybus L. plant treated with different concentrations of endothall and cantharidin (A), changes in the activity of glutathione peroxidase enzyme in the shoot samples of Chicorium intybus L. with different concentrations of endothall and cantharidin (B) ${ }^{* *}$ Representing significant effects at $0.1 \%$ probability level.

oxidase was observed in the treatment groups with the endothall concentrations of 5.5 and $2.5 \mu \mathrm{g} \mathrm{ml}{ }^{-1}$, as well as in the shoots of those with the cantharidin concentrations of 2.5 and $2.5 \mu \mathrm{g} \mathrm{ml}^{-1}$. Furthermore, the maximum elevation of the gene expression of catalase in the roots of the samples treated with endothall and cantharidin was observed at the concentrations of 10 and $5.5 \mu \mathrm{g} \mathrm{ml}^{-1}$, respectively. As for glutathione peroxidase, the maximum elevation was denoted at the concentration of $5.5 \mu \mathrm{g} \mathrm{ml}^{-1}$.

In the mentioned treatment groups, the activity of catalase and glutathione peroxidase increased, suggests the onset of damage to the plant and activation of the antioxidant defense mechanism. In addition, treatment with cantharidin exerted more significant effects on the activity of catalase and glutathione peroxidase compared to endothall. In other words, the induction of damage to the plant initiated at lower concentrations, leading to a stronger response in the plant. However, the intensity and peak of the catalase and glutathione peroxidase activity declined at higher concentrations, which could be due to damage to the shoot or root cells since the elevated endothall and cantharidin concentrations may have partly eliminated the cellular response. Consistently, the results of the present study indicated that the level of antioxidant enzymes increased in the plants treated with cantharidin.

In this regard, Bajsa et al. (2012b) examined the effects of cantharidin on the biology of Arabidopsis. According to the obtained results, most of the protein detected 
Table 2: Analysis of variance for the effect of endothall and cantaridin on shoot and root of Chicorium intybus L. under catalase treatment

\begin{tabular}{llll}
\hline & df & Shoot CAT & Root CAT \\
\hline Model & 15 & $0.140 \mathrm{n} . \mathrm{s}$ & $0.100 \mathrm{n} . \mathrm{s}$ \\
Endotal 2.5 & 5 & $0.120 \mathrm{n} . \mathrm{s}$ & $0.100 \mathrm{n} . \mathrm{s}$ \\
Endotal 5.5 & 5 & $0.200 \mathrm{n} . \mathrm{s}$ & $0.100 \mathrm{n} . \mathrm{s}$ \\
Endotal 10 & 5 & $0.170 \mathrm{n} . \mathrm{s}$ & 0.190 \\
Error & - & 0.140 & 0.140 \\
C.V. & - & 7.49 & 4.39 \\
Model & 15 & $0.140 \mathrm{n} . \mathrm{s}$ & $0.100 \mathrm{n} . \mathrm{s}$ \\
Cantaridin 2.5 & 5 & $0.515^{\star * *}$ & $0.420^{* * *}$ \\
Cantaridin 5.5 & 5 & $0.300^{* * *}$ & $0.560^{* * *}$ \\
Cantaridin 10 & 5 & $0.330^{* * *}$ & $0.300^{* * *}$ \\
Error & - & 0.101 & 0.150 \\
C.V. & - & 8.14 & 7.28 \\
\hline
\end{tabular}

Table 3: Analysis of variance for the effect of endothall and cantaridin on shoot and root of Chicorium intybus L. under glutation peroxidase treatment

\begin{tabular}{llll}
\hline & df & Shoot GPX & Root GPX \\
\hline Model & 45 & $0.270 \mathrm{n} . \mathrm{s}$ & $0.340 \mathrm{n} . \mathrm{s}$ \\
Endotal 2.5 & 15 & $0.380 \mathrm{n} . \mathrm{s}$ & $0.330 \mathrm{n} . \mathrm{s}$ \\
Endotal 5.5 & 15 & $0.600 \mathrm{n} . \mathrm{s}$ & $0.230 \mathrm{n} . \mathrm{s}$ \\
Endotal 10 & 15 & $0.350 \mathrm{n} . \mathrm{s}$ & $0.440 \mathrm{n} . \mathrm{s}$ \\
Error & - & 0.071 & 0.040 \\
C.V. & - & 12.23 & 7.01 \\
Model & 45 & $0.270 \mathrm{n} . \mathrm{s}$ & $0.340 \mathrm{n} . \mathrm{s}$ \\
Cantaridin 2.5 & 15 & $0.840^{* * *}$ & $0.560^{\star * *}$ \\
Cantaridin 5.5 & 15 & $0.600^{* * *}$ & $0.860^{* * *}$ \\
Cantaridin 10 & 15 & $0.740^{* * *}$ & $0.740^{\star * *}$ \\
Error & - & 0.061 & 0.040 \\
C.V. & - & 12.18 & 13.16 \\
\hline
\end{tabular}

in the chloroplast diminished significantly, especially the proteins involved in photosynthesis. Conversely, the specific enzymes increased 1.5-3.3 times, especially glutathione transferase. Since the main role of glutathione transferase (antioxidant enzyme) is to induce defense and detoxification in plant tissues, this finding suggested that cantharidin may stimulate defense responses (Akram, 2012), and one of the defense modes is the election of antioxidant enzymes in the plant. In another study, the mechanism of action of endothall was investigated in plants. The biological tests for examining the physiological effects of endothall demonstrated that this herbicide exerted phytotoxic effects. Unlike other detrimental herbicides, endothall does not inhibit the polymerization of tubulin under experimental conditions. These effects have also been observed after treatment with the inhibitors of phosphatase protein, cantharidin, and okadaic acid (Tresch, 2011). Peksel (2013) found out that syntetic compounds as norcantharidin shows antioxidant activities in vitro condition.

According to the present study, high concentrations of endothall and cantharidin led to the inhibition of plant growth, which could be due to the inhibition of the cell cycle. At lower concentrations, the enhanced activity and expression of these antioxidant genes could be observed in plants, which may be due to the activation of the defense mechanism of the plant against harmful effects and oxidative stress (Tresch, 2011a). In another research, the 
findings indicated that the activation of the catalase and peroxidase enzymes by silver nitrate could cause these enzymes to cooperate in the removal of hydrogen peroxide. Additionally, this was reported to be the main cause of the initiation of the antioxidant defense, so that the inadequate response of an enzyme to silver nitrate could be compensated for through elevating the activity of another enzyme (Shabani \& Saghirzadeh, 2015). Moreover, the present study showed that the antioxidant defense occurred at low concentrations and with higher intensity in the samples treated with cantharidin, which could be considered as an opportunity for the higher effectiveness of endothall. As reported by Tresch (2011b), the performance of endothall phosphatase anti-protein in plants is more effective compared to cantharidin. These effects may partly originate from the inhibition of the effects of cantharidin at low concentrations through the antioxidant defense system.

The findings of the present research indicated that endothall and cantharidin phytotoxins cause changes in the activity and expression of oxidative stress enzymes, such as catalase and glutathione peroxidase. These enzymes convert free radicals into water and are among the most active barriers against oxidative reactions in plant cells (Arora, 2002). As has been demonstrated in corn roots, endothall deviates cell division and the orientation of the microtubule structure, thereby disrupting the cell cycle in the prometaphase phase. In addition, endothall has been reported to exert other effects, such as the compression of cell nuclei, inhibiting the DNA synthesis phase, and inducing extra mutations in plant cells. These effects are closely correlated with oxidative stress (Tresch, 2011c). Li et al. (2014) use ROS signaling in mutations CAT2, it's an antioxidant enzyme model for study the contributed factors in ROS signaling (Mhamdi et al., 2010).As reported previously, herbicides cause damage to plants, which mostly occurs through the production of reactive oxygen species (ROS) like superoxide radical, $\mathrm{OH}$ radicals and $\mathrm{H}_{2} \mathrm{O}_{2}$ (Gill \& Tutja, 2010). Accordingly, the activity of antioxidant enzymes, which is closely associated with ROS, is considered an index of various biological stress. High levels of antioxidants in a plant cells may provide a special stress resistance (Nohatto et al., 2016). Under such circumstances, the elevated activity of one or several antioxidants may occur, thereby stimulating the resistance (Akram, 2012a). The antioxidant enzyme's roll in stress controls ROS gathering and limiting oxidative injuries (Nohatto et al., 2016a).

\section{CONCLUSIONS}

The present study aimed to compare the effects of endothall and cantharidin herbicides on the changes in the gene expression and activity of the catalase and glutathione peroxidase enzymes that disorder signaling pathways by blocking the protein phosphatase gene expression in shoot and root of this plant and decrease growth parameters. The findings of this present research show the catalase and glutathione peroxidase activity increased the samples treated cantharidin and endothall compared to the controls, suggesting the initiation of antioxidant activity in the plant.

\section{REFERENCES}

Abbas, Z. K., Saggu, S., Sakeran, M.I., Zidan, N., Rehman, H., \& Ansari, A.A. (2015). Phytochemical, antioxidant and mineral composition of hydroalcoholic extract of chicory (Cichorium intybus L.) leaves. Saudi Journal Biological Sciences, 22(3), 322-326. http://dx.doi.org/10.1016/j. sjbs.2014.11.015

Akram, N.A., Ashraf, M., \& Al-Qurainy, F. (2012). Aminolevulinic acid-induced changes in some key physiological attributes and activities of antioxidant enzymes in sunflower (Helianthus annuus L.) plants under saline regimes. Scientia Horticulturae, 142, 143-148. http://dx.doi.org/10.1016/j. scienta.2012.05.007

Arora, A., Sairam, R.K., \& Srivastava, G.C. (2002). Oxidative stress and antioxidative system in plants. Current Science Association, 82, 1227-1238. http://doi.org/10.2307/jstor.24107045

Bais, H.P., Ravishankar, G.A. (2001). Cichorium intybus L. cultivation, processing, utility, value addition and biotechnology, with an emphasis on current status and future prospects. Journal of the Science of Food and Agriculture, 467-484. https://doi.org/10.1002/jsfa.817

Bajsa, J., Pan, Z., \& Duke, S.O. (2011). Transcriptional responses to cantharidin in Arabidopsis thaliana reveal the involvement of multiple signal transduction pathways. Physiologia Plantarum, 188-205. https://doi.org/10.1111/ j.1399-3054.2011.01494.x

Bajsa, J., Pan, Z., Dayan, F.E., Owens, D.K. \& Duke, S.O. (2012). Validation of serine/threonine protein phosphatase as the herbicide target site of endothall. Pesticide Biochemistry and Physiology, 102(1), 38-44. https://doi.org/10.1016/j. pestbp.2011.10.007

Dayan, F.E., Watson, S.B. (2011). Plant cell membrane as a marker for light-dependent and light-independent herbicide mechanisms of action. Pesticide Biochemistry and Physiology, 182-190. https://doi.org10.1016j.pestbp.2011.09.004

Duke, S.O., Powles, S.B. (2008). Glyphosate: a once in a century herbicide. Pest Management Science, 319-325. http://doi. org/10.1002/ps.1518

Funk, V.A., Bayer, R.J., Keeley, R.J., Chan, R., Watson, L., Gemeinholzer, B., \& Schilling, E. (2005). Everywhere but Antarctica: using a supertree to understand the diversity and distribution of the Compositae. Biologiske Skrifter, 55, 343-374. 
Gill, S.S., Tuteja, N. (2012). Reactive oxygen species and antioxidant machinery in abiotic stress tolerance in crop plants. Plant Physiology and Biochemistry, 48(12), 909-930. http:// doi.org/10.1016/j.plaphy.2010.08.016

Heimler, D., Isolani, L.Vignolini, P., \& Romani, A. (2009). Polyphenol content and antiradical activity of Cichorium intybus L. from biodynamic and conventional farming. Food Chemistry, 114(3), 765-770. https://doi.org/10.1016/j.foodchem.2008.10.010

Li, S.C., Mhamdi, A., Trotta, A., Kangasjärvi, S., \& Noctor, G. (2014). The protein phosphatase subunit PP2A-B1 $\gamma$ is required to suppress day length-dependent pathogenesis responses triggered by intracellular oxidative stress. New Phytologist, 202(1), 145-160. https://doi.org/10.1111/ nph. 12622

Mac, A., Nelson, C.J., \& Sharp, R.E. (1992). Peroxidase activity in the leaf elongation zone of tall fescue. Plant Physiology, 99(3), 294-878. https://dx.doi.org/10.1104.pp.99.3.872

Marschner, H., Cakmak, I. (1992). Mangnesium definciency and high light intensity enhance activities of superoxide dismutase and glutathione reductase i bean leaves. Plant physiology, 98(4), 1222-1227. https://dx.doi.org/10.1104/ pp.98.4.1222

Mhamdi, A., Queval, G., Chaouch, S., Vanderauwera, S., van Breusegem, F., \& Noctor, G. (2010). Catalase function in plants: A focus on Arabidopsis mutants as stress-mimic models. Journal of Experimental Botany, 61(15), 4197-4220. https://doi.org/10.1093/jxb/erq282
Nohatto, M.A., Agostinetto, D., Langaro, A.C., de Oliveira, C., \& Ruchel, Q. (2016). Antioxidant activity of rice plants sprayed with herbicides. Pesquisa Agropecuária Tropical, 46(1), 2834. https://doi.org/10.1590/1983-40632016v4638011

Peksel, A., Celik, C., Ocal, N., \& Yanardag, R. (2013). Antioxidant and radical scavenging activities of some norcantharidin and bridged perhydroisoindole derivatives. Journal of the Serbian Chemical Society, 78(1), 15-25. https://doi. org/10.2298/JSC120123036P

Sanders, NA., Lee, MA. (2013). Real time PCR: Advanced technologies and applications. Caister Academic Press

Senderski, M.E. (2009). Praktyczny poradnik o ziołach i ziołolecznictwie herbs. A practical guide to herbs and herbal medicine. Warszawa, 102-103.

Tresch, S., Schmotz, J., \& Grossmann, J. (2011). Probing mode of action in plant cell cycle by the herbicide

endothall, a protein phosphatase inhibitor. Pesticide Biochemistry and Physiology, 99(1), 86-95. https://doi.org/10.1016/j. pestbp.2010.11.004

Ward, G.C., Joo, J., Ramien, M., \& Ying, Y. (2017). Extensive chemical burns in a child from misuse of cantharidin: a case report. Universiy of Ottawa Journal of Medicine, 7(1), 64-67. https://doi.org/10.18192/uojm.v7i1.1999

Young, D.K. (1984). Field studies of cantharidin orientation by Neopyrochroa flabellata (Coleoptera: Pyrochroidae). Great Lakes Entomologist, 17(3), 1-4. https://scholar.valpo.edu/ tgle/vol17/iss3/4 